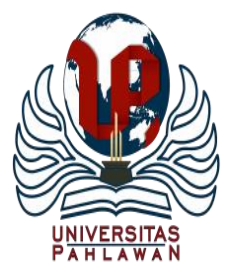

Edukatif : Jurnal Ilmu Pendidikan Volume 3 Nomor 5 Tahun 2021 Halm 3062 - 3071

EDUKATIF: JURNAL ILMU PENDIDIKAN

Research \& Learning in Education

https://edukatif.org/index.php/edukatif/index

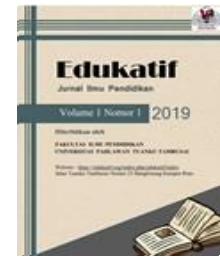

\title{
Analisis Karakter Disiplin dan Tanggung Jawab Siswa Sekolah Dasar pada Masa Pembelajaran Daring
}

\author{
Reni Sofia Melati ${ }^{1 凶}$, Sekar Dwi Ardianti², Much Arsyad Fardani ${ }^{3}$ \\ Universitas Muria Kudus, Indonesia ${ }^{1,2,3}$ \\ E-mail : renisofia49@gmail.com ${ }^{1}, \underline{\text { sekar.dwi.ardianti@ umk.ac.id }}^{2}, \underline{\text { danikudus1990@gmail.com }}^{3}$
}

\begin{abstract}
Abstrak
Tujuan dari penelitian ini adalah untuk mengetahui dan menganalisis karakter disiplin dan tanggung jawab siswa sekolah dasar di masa pembelajaran daring. Penelitian ini menggunkan jenis penelitian kualitatif deskriptif dengan subjek penelitian empat orang tua dan empat anak sekolah dasar. Penelitian ini telah dilaksankan di Desa Ngawen RT 4 RW 2 Kecamatan Margorejo Kabupaten Pati. Metode pengumpulan data menggunakan observasi, wawancara, dan dokumentasi. Analisis data yang digunakan ialah analisis data kualitatif dengan mengacu pada konsep Miles dan Huberman yaitu reduksi data, penyajian data, dan penarikan kesimpulan. Hasil dari penelitian ini menunjukkan bahwa selama pandemi tidak semua anak memilik sikap disiplin dan tanggung jawab yang baik selama pembelajaran daring. Sebelum pembelajaran daring siswa menaati tata tertip dan bertanggung jawab terhadap tugasnya. Faktor yang menghambat penanaman karakter disiplin dan tanggung jawab siswa adalah dari faktor eksternal yaitu handphone dan televisi. Faktor internal yang mempengaruhi tanggung jawab adalah rasa malas dalam diri siswa yang menyebabkan siswa menunda menyelesaikan tugas sekolah.
\end{abstract}

Kata Kunci: Karakter Disiplin, Karakter Tanggung Jawab, Pembelajaran Daring.

\begin{abstract}
The purpose of this study was to determine and analyze the character of discipline and responsibility of elementary school students in the online learing period. This researchuses descriptive qualitative with research subjects four perents and four elementary school children. This research has been carried out in Ngawen Village RT $4 R W$ 2, Margorejo District, Pati Regency. Methods of data collection using observation, interviews, and dokumentation. The data analysis used is qualitative data analysis with reference to the concept of Miles and Huberman, namely data reduction, data presentation, and drawing conclusions. The result of this study indicate that during the pandemic not all childern have a good attitude of disclipine and responsibility during online learning. Before online learning, students obey the rules and are responsible for their duties. Factors that hinder the cultivation of students' disclipine and responbility chacarters are external factors, namely handphone and television. The internal factor that affects responbility is a sense of laziness in students which causes students to delay completing school assignments.
\end{abstract}

Keywords: Disclipine Character, Responsibility, Online Learning

Copyright (c) 2021 Reni Sofia Melati, Sekar Dwi Ardianti, Much Arsyad Fardani

$\square$ Corresponding author

Email : renisofia49@gmail.com

DOI : https://doi.org/10.31004/edukatif.v3i5.1229

ISSN 2656-8063 (Media Cetak)

ISSN 2656-8071 (Media Online) 
3063 Analisis Karakter Disiplin dan Tanggung Jawab Siswa Sekolah Dasar pada Masa Pembelajaran Daring - Reni Sofia Melati, Sekar Dwi Ardianti, Much Arsyad Fardani

DOI: https://doi.org/10.31004/edukatif.v3i5.1229

\section{PENDAHULUAN}

Pendidikan diharapkan mampu meciptakan generasi yang memiliki kecerdasan intelektual, lifeskill, dan karakter yang baik. Hal ini sesuai dengan tujuan pendidikan nasional dalam Undang Undang No 20 Tahun 2003 tentang Sistem Pendidikan Nasional. Penguatan pendidikan karakter muncul karena semakin banyaknya degradasi moral dan karakter generasi muda. Hal ini dikarenakan pendidikan yang selama ini berlangsung hanya fokus pada aspek intelektual atau kognitif. Degradasi moral yang terjadi dapat dibenahi dengan adanya pendidikan karakter (Asyari et al., 2021). Pendidikan diartikan sebagai proses memberi pengetahuan, sedangkan karakter adalah watak, kebiasaan, dan sikap yang membedakan antar individu lainnya. Pendidikan karakter merupakan pendidikan moral yang ditanamkan dalam diri peserta didik (sekolah dasar) berupa nilainilai yang tidak terlepas dari keseharian dalam proses pembelajaran (Dole, 2021). Hal tersebut sejalan dengan pendapat Wanabiwulandari (2018) tanpa pendidikan karakter, seseorang dapat berbuat apa saja walaupun merugikan orang lain. karakter anak sangat berpengaruh terhadap nasib suatu bangsa.

Terdapat nilai karakter yang dianggap penting dalam menunjang kegiatan pembelajaran yaitu Disiplin dan Tanggung Jawab. Lickona (2013) mengatakan bahwa disiplin harus memperkuat karakter siswa, sematamata bukan mengontrol perilaku mereka. Begitu juga menurut Yasin(2018) disiplin adalah tindakan yang menunjukkan kepatuhan dan ketaatan karena adanya kesadaran dorongan dari diri sendiri terhadap peraturan dan tidak melanggarnya. Disiplin menurutnya sebagai tindakan yang patuh karena keinginan dalam diri sendiri tanpa ada paksaan dari luar serta kegiatan yang dilakukan tidak melanggar peraturan. Menurut Ningrum (2020) menyebutkan bahwa disiplin merupakan perilaku kepatuhan seseorang terhadap suatu aturan yang berlaku. Disiplin berperan penting dalam menentukan kesuksesan belajar peserta didik dan banyak manfaat lain apabila peserta didik menerapkan sikap kedisiplinan. Dapat disimpulkan bahwa disiplin merupakan sebuah sikap atau perilaku yang dimiliki oleh seorang individu yang menunjukkan adanya kepatuhan, ketaatan, dan ketertibatan terhadap aturan dan norma kehidupan yang berlaku. Disiplin dalam diri seseorang merupakan bentuk kesadaran dalam diri individu untuk melakukan sesuatu sesuai nilai, norma dan aturan yang berlaku di masyarakat. Memandang bahwa kedisiplinan termasuk pendidikan moral dan sebagai bagian dari pendidikan anak. Lebih lanjut dikatakan bahwa masalah moral semakin memprihatinkan dan meningkat dari tahun ketahun. Karena itulah, sekolah mulai mengedepankan pendidikan karakter bagi siswa melalui contoh-contoh kedisiplinan.

Indikator karakter disiplin menurut Patmawati (2018) adalah (1) datang tepat waktu, (2) patuh pada tata tertip atau aturan bersama/sekolah, (3) mengerjakan/mengumpulkan tugas sesuai dengan waktu yang ditentukan, dan (4) mengikuti kaiadah berbahsa yang baik dan benar. Indikator menurut Prastika (2018) adalah (1) datang ke sekolah dan pulang dari sekolah tepat waktu, (2) patuh pada tata tertip atau aturan sekolah, (3) mengerjakan setiap tugas yang diberikan,(4) mengumpulkan tugas tepat waktu, mengikuti kaidah berbahasa yang baik dan benar, (5) memakai seragam sesuai ketentuan yang berlaku, dan (6) membawa perlengkapan belajar sesuai dengan mata pelajaran. Selanjutnya indikator menurut Uddiin (2016) adalah menyatakan bahwa indikator disiplin adalah selalu (1) datang tepat waktu, (2) dapat memperkirakan waktu yang diperlukan untuk menyelesaikan sesuatu, (3) menggunakan benda sesuai dengan fungsinya, (4) mengambil dan mengembalikan benda pada tempatnya, (5) berusaha menaati aturan yang disepakati, (6) tertib menunggu giliran, (7) dan menyadari akibat bila tidak disiplin. Pada penelitian ini menggunakan indikator (1) datang tepat waktu, (2) patuh pada tata tertib atau aturan, dan (3) menyelesaikan tugas dengan tepat waktu yang ditentukan.

Selanjutnya tanggung jawab adalah mampu mempertanggung jawabkan serta memiliki perasaan untuk memenuhi tugas dengan dipercaya, mandiri, dan berkomitmen (Zubaedi, 2011). Tanggungjawab merupakan suatu keadaan wajib menanggung segala sesuatu atas perbuatan yang telah dilakukan. Menurut Samani dan Hariyanto (2020) menjelaskan bahwa tanggung jawab merupakan sebuah sikap dalam diri seseorang yang 
3064 Analisis Karakter Disiplin dan Tanggung Jawab Siswa Sekolah Dasar pada Masa Pembelajaran Daring - Reni Sofia Melati, Sekar Dwi Ardianti, Much Arsyad Fardani

DOI: https://doi.org/10.31004/edukatif.v3i5.1229

menunjukkan sikap mengetahui dan melaksanakan apa yang dilakukan sebagaimana yang diharapkan oleh orang lain. Wanabuliandari (2018) mengungkapkan bahwa seorang peserta didik dapat ditanamkan karakter tanggung jawab jika terbiasa bertindak bertanggung jawab terutama terhadap lingkungannya. dapat simpulkan bahwa tanggug jawab merupakan sikap atau perilaku individu yang mau melaksanakan tugas dan kewajibannya baik terhadap diri sendiri, orang lain, terhadap masyarakat dan negara serta kewajiban Tuhan.

Seseorang dikatakan sudah bertanggung jawab apabila dia sudah memperlihatkan indikator tanggung jawab. Indikator tanggung jawab menurut Triyani dkk (2020) sebagai berikut, (1) mengerjakan tugas dan pekerjaan rumah dengan baik, (2) bertanggung jawab terhadap setiap perbuatan, (3) melakukan piket sesuai dengan jadwal yang telah ditetapkan, dan (4) mengerjakan tugas kelompok secara bersama-sama. Indikator tanggung jawab menurut Resti (2017) adalah sebagai berikut, (1) memilih jalan lurus, (2) selalu memajukan diri sendiri, (3) menjaga kehormatan diri, (3) selalu waspada, (4) memiliki komitmen pada tugas, (5) melakukan tugas dengan standart yang baik, (6) mengakui semua perbuatannya, (7) menepati janji dan (8) berani menanggung resiko atas tindakan dan ucapannya. Sedangkan menurut Rahayu (2016) indikator tanggung jawab yaitu (1) menggunakan waktu secara efektif, (2) melakukan persiapan sebelum pembelajaran, (3) melaksanakan proses diskusi, dan (4) mengerjakan soal atau permasalahan dengan teliti. Berdasarkan penjabaran di atas, maka indikator tanggung jawab yang digunakan dalam penelitian ini adalah (1) mengerjakan tugas dan pekerjaan rumah dengan baik, (2) bertanggung jawab terhadap setiap perbuatan, (3) menggunakan waktu secara efektif, (4) dan mengerjakan tugas kelompok dengan diskusi.

Usaha untuk mewujudkan tujuan pendidikan nasional dengan melalui penguatan pendidikan karakter, sistem pendidikan di Indonesia harus mengalami beberapa kendala akibat pandemi Covid-19. Pandemi Covid19 memiliki dampak besar pada berbagai bidang kehidupan, salah satunya adalah bidang pendidikan. Agar memperlambat laju penyebaran Covid-19, maka Kementrian Pendidikan dan Kebudayaan Republik Indonesia melaksanakan sistem pembelajaran jarak jauh atau disebut dengan pembelajaran daring. Pembelajaran daring, atau dalam jaringan adalah terjemahan dari istilah online yang bermakna tersambung ke dalam jaringan komputer. Dengan kata lain merupakan pembelajaran tanpa muka secara langsung antara guru dan siswa, tetapi dilakukan melalui jaringan internet (online) dari tempat yang berbeda-beda. Menurut Hapsari dkk (2021) pembelajaran daring merupakan pembelajaran yang dilakukan dengan menggunakan perangkat elektronika seperti jasa audio, video, atau perangkat komputer atau kombinasi dari ketiganya. Selajalan dengan Ardiana dkk (2020) menyatakan bahwa pembelajaran daring merupakan pembelajaran yang mengguakan jaringan internet dengan aksesbilitas, konektivitas, fleksibilitas, dan kemampuan untuk memunculkan berbagai jenis interaksi baru. Pohan (2020) pembelajaran daring adalah pembelajaran yang berlangsung di dalam jaringan internet dimana guru tidak bertatap muka dengan siswa. Berdasarkan penjabaran diatas, maka dapat disimpulkan bahwa pembelajaran daring adalah proses kegiatan belajar mengajar yang dilakukan dengan memanfaatkan jaringan internet sehingga siswa maupun guru dapat mengikuti pembelajaran tanpa tatap muka secara langsung.

Perubahan kegiatan belajar mengajar secara langsung menjadi kegitan mengajar dari rumah (daring) merupakan revolusi sistem pendidikan di Indonesia. Pembelajaran daring yang dilaksanakan diharapkan tetap mampu menerapkan serta menanamkan pendidikan karakter dalam diri siswa. Melalui pembelajaran daring, pendidikan karakter tidak hanya menjadi tanggung jawab sekolah melainkan tanggung jawab keluarga dan lingkungan sekitar siswa. Lingkungan sekitar siswa memiliki pengaruh terhadap proses penguatan pendidikan karakter khususnya karakter tanggung jawab dan disiplin. Peran keluarga sangatlah besar dalam proses pendidikan anak dimasa pandemi karena perubahan proses pendidikan dan pembelajaran dari taatp muka menjadi tatap maya (Rangga et al., 2021).

Seperti halnya hasil observasi dan wawancara dengan orang tua dan peserta didik di Desa Ngawen yang mengalami penuruan sikap disiplin dan tanggung jawab, contohnya anak terlambat mengumpulkan tugas, anak sulit untuk memahami materi pembelajaran, kemalasan anak, anak lebih suka bermain game daripada 
3065 Analisis Karakter Disiplin dan Tanggung Jawab Siswa Sekolah Dasar pada Masa Pembelajaran Daring - Reni Sofia Melati, Sekar Dwi Ardianti, Much Arsyad Fardani

DOI: https://doi.org/10.31004/edukatif.v3i5.1229

mmengikuti pembelajaran daring, anak lebih sering menonton TV, anak selalu menganggap bahwa sekolah diliburkan akibat pandemi Covid-19, dan kurangnya pantauan dari orang tua terhadap penggunaan HP sehingga anak menyalahgunakan fungsi HP untuk bermain game. Penelitian terdahulu oleh Ratri (2016) juga menunjukkan bahwa anak SD masih belum memiliki kesadaran dalam bersikap disiplin dan tanggung jawab terhadap belajarnya, sehingga masih diperlukan analisis karakter disiplin dan tanggung jawab terhadap anak. Hal ini sejalan dengan penelitian yang dilakukan oleh Ramadhani dkk (2020), menunjukkan bahwa selama pandemi Covid-19, ada beberapa masalah yang tampak, seperti ada orang tua yang memberlakukan HP sebagai sahabat anak ketika anak merasa bosan, kurangnya upaya pengendalian orang tua pada dunia anak, masalah orang tua dalam menghadapi anak kejenuhan orang tua dan anak selama masa pandemi ini.Penelitian ini bertujuan untuk menganalisis karakter disiplin dan tanggung jawab anak SD pada masa pembelajaran daring. Analisis karakter disiplin dan tanggung jawab kepada anak sangat diperlukan untuk dapat mengetahui faktor-faktor yang menyebabkan anak mengalami penurunan dan mengetahui solusi penanganannya untuk membuat karakter disiplim dan tanggung jawab anak lebih baik dimasa pembelajaran daring akibat salahnya penggunaan HP pada anak. Dari contoh penelitian terdahulu yang dilakukan oleh Ratri belum menjelaskan tentang karakter disiplin dan tanggung jawab anak SD di masa pandemi, hanya menjelaskan bahwa anak SD belum mempunyai kesadaran dalam bersikap disiplin dan tanggung jawab.

Berdasarkan teori disiplin menurut Kemdiknas (2010) mendefinisikan bahwa, disiplin adalah suatu tindakan yang menunjukkan perilaku tertib dan patuh pada berbagai ketentuan dan peraturan. Sedangkan dalam penelitian ini, karakter disiplin yang ditujukan kepada anak SD hanya berdasarkan peraturan yang tidak tertulis, akan tetapi harus dipatuhi oleh siswa tersebut secara langsung. Hal ini dapat disimpulkan bahwa disiplin merupakan sikap tertib dan patuh dengan suatu peraturan, tidak anya peraturan tertulis, melainkan peraturan yang tidak tertulis juga. Sedangkan karakter yang kedua adalah karakter tanggung jawab, Muchlas dan Hariyanto (2020) menjelaskan bahwa tanggung jawab merupakan sebuah sikap dalam diri seseorang yang menunjukkan sikap mengetahui dan melaksanakan apa yang dilakukan sebagaimana yang diharapkan oleh orang lain. Kemudian dalam penelitian yang saya lakukan, siswa kurang mempunyai sikap tanggung jawab. Hal ini dapat ditunjukkan dengan contoh yang peneliti temukan yaitu senang menunda pekerjaan, senang telat mengumpulkan tugas, dan terlambat mengikuti pembelajaran daring. Hal ini dapat disimpulkan bahwa adanya kesenjangan teori karakter disiplin dan tanggung jawab yang dilakukan oleh siswa dibandingkan teori yang ada. Penelitian ini bertujuan untuk berusaha menganalisis karakter disiplin dan tanggung jawab anak SD pada masa pembelajaran daring. Sehingga dapat menganalisis karakter disiplin dan tanggung jawab anak SD secara lebih ilmiah.

\section{METODE PENELITIAN}

Peneliti melakukan penelitian dengan menggunakan penelitian kualitatif, pengumpulan data yang peneliti dilakukan kepada 4 anak SD. Kolaborator dalam penelitian ini adalah orang tua anak SD yang mendampingi dan ikut diwawancarai sebagai informan oleh peneliti. Penelitian menggunakan tiga teknik dalam pengumpulan data yaitu observasi, wawancara, dan dokumentasi. Dalam kegiatan observasi, peneliti ikut berpartisipasi dengan cara mengikuti kegiatan pembelajaran melalui daring sebagai peserta. Observasi selanjutnya peneliti mengamati sikap orang tua dalam memberikan pengajaran kepada anaknya terkait sikap sopan dan santun. Sedangkan kegiatan wawancara dilakukan dengan cara peneliti mengajukan beberapa pertanyaan kepada siswa dan orangtua siswa mengenai karakter disiplin da tanggung jawab saat pembelajaran daring. Kemudian dokumentasi dilakukan dengan mendokumentasikan penelitian mulai dari saat dimulai pembelajaran daring, proses pengerjaan tugas yang diberikan oleh guru SD hingga proses pembelajaran selesai. Penelitian ini dilaksanakan di Desa Ngawen RT 4 RW 2 Kecamatan Margorejo Kabupaten Pati selama 1 bulan mulai bulan April hingga Mei 2021. Teknik keabsahan data yang dilakukan dalam penelitian ini 
3066 Analisis Karakter Disiplin dan Tanggung Jawab Siswa Sekolah Dasar pada Masa Pembelajaran Daring - Reni Sofia Melati, Sekar Dwi Ardianti, Much Arsyad Fardani

DOI: https://doi.org/10.31004/edukatif.v3i5.1229

meliputi: kredibilitas, tranferabelitas, dependabilitas, dan konfirmabilitas. Kredibilitas dilakukan degan perpanjangan pengamatan dan triangulasi data. Transferabelitas dilakukan dengan pengecekan melalui transferability dengan diuraikannya hasil penelitian secara rinci, jelas dan sistematis. Dependabilitas dilakukan dengan dosen pembimbing melakukan pengecekan terhadap hasil penelitian. Kemudian konfirmabilitas dilakukan bersamaan dengan dosen pembimbing pada tahap dependabilitas. Analisis data yang digunakan mengacu pada konsep Miles dan Huberman, yaitu pengumpulan data, reduksi data, penyajian data, dan penarikan kesimpulan.

\section{HASIL DAN PEMBAHASAN PENELITIAN}

Penelitian ini dilaksanakan di Desa Ngawen RT 4 Rw 2 Kecamatan Margorejo Kabupaten Pati pada bulan April 2021 hingga bulan Mei 2021. Berdasarkan hasil penelitian didapatkan beberapa faktor yang mempengaruhi karakter disiplin siswa SD selama pembelajaran daring. Peneliti menemukan faktor yang menghambat penanaman karakter pada anak selama masa pandemi.

Faktor yang menjadi penghambat dalam penanaman karakter anak adalah pembelajaran daring tidak leluasa seperti pembelajaran luring, sehingga guru tidak dapat menanamkan nilai karakter yang bervariatif. Guru hanya mempercayakan orang tua dan lingkungan keluarga untuk membentuk karakter anak selama pembelajaran daring. Prabowo dkk (2020), dalam penelitiannya menjelaskan bahwa selama masa pandemi, orang tua memiliki peran yang lebih besar untuk membentuk karakter anak, namun akibat pembelajaran daring, menenjadi tantangan bagi orang tua dalam membimbing dan mengawasi anak, pasalnya anak lebih cenderung bermain gadget yang terkadang disalahgunakan.

Berdasarkan hasil penelitian didapatkan beberapa faktor yang mempengaruhi karakter disiplin siswa SD selama pembelajaran daring. Peneliti menemukan faktor yang menghambat penanaman karakter pada anak selama masa pandemi. Faktor yang mengahambat penanaman karakter ini adalah faktor eksternal yaitu televisi dan bermain game. Hasil observasi pada objek penelitian pertama yaitu RZA menunjukan bahwa RZA belum mampu mengerjakan tugas sekolah sendiri denga baik tanpa adanya bantuan dari oran lain sehingga RZA dikategorikan memiliki karakteristik tanggung jawab yang rendah. RZA selalu mengulur waktu dan juga terburu-buru ketika sedang mengerjekan tugas yang diberikan oleh guru. Anak juga terkadang malas karena sering bermain game. Hal ini sesuai dengan apa yang disampaikan oleh orang tua RZA.

" $\mathrm{Bu}$, anak mempunyai sikap mandiri dalam melaksankan tanggung jawan dirumah selama pembelajaran daring tidak?"

"iyam mbak, karena saya selalu menuntut anak untuk selalu bertanggung jawab terhadap sesuatu hal yang dilakukannya. Namun, juga masih butu bantuan mengerjakan tugasnya."

"Apa ada faktor lain yang mengakibatkan anak meminta bantuan untuk mengerjakan tuganya?"

"Anak terburu-buru mengerjakan tugas dikarenakan ingin cepat-cepat bermain game."

"Anak lebih suka bermain game online di HP"

"Anak lebih tertarik bermain game bersama teman-temannya daripada mengerjakan tugas dari gurunya." (25 April 2021)

RZA tidak menggunakan waktu belajar dengan baik dan maksimal. Hal ini dikarenakan anak lebih suka menghabiskan waktunya untuk bermain handphone. RZA kurang suka menyelesaikan tugas sekolah lebih awal. Meskipun RZA teratur dan bertanggung jwab terhadap tugas rumah namun untuk tugas sekolah RZA kurang teratur atau bertanggung jawab terhadap tugas berikut. Hal ini sesuai dengan apa yang disampaikan oleh orang tua RZA.

"Selama pembelajran daring apa anak menggunakan waktunya untuk belajar dengan baik, Bu?"

"Tidak mbak, anak lebih suka bermain HP dari pada belajar materi dari gurunya."

"Anak teratur dalam tugas rumah tetapi tidak teratur dalam tugas sekolah.” (25 April 2021) 
3067 Analisis Karakter Disiplin dan Tanggung Jawab Siswa Sekolah Dasar pada Masa Pembelajaran Daring - Reni Sofia Melati, Sekar Dwi Ardianti, Much Arsyad Fardani

DOI: https://doi.org/10.31004/edukatif.v3i5.1229

Dampak dari faktor yang menghambat dalam penerapan karakter disiplin selama pembelajaran daring adalah anak sering mengulur waktu untuk mengrjakan dan mengumpulkan tugas yang diberikan oleh guru. Dalam penelitian Larasati (2017) mengungkapkan bahwa faktor penghambat pendidikan karakter pada peserta didik SDIT Al Muhajirin yakni peserta didik sendiri yang terbiasa dengan kebiasaan yang buruk serta pengaruh buruk dari kondisi perilaku orang tua dan lingkungan sekitar seperti teman sebaya dan lain-lain. Hal ini didukung dengan hasil observasi yang menunjukkan bahwa RZA sering terlambat dalam pengumpulan tugas kepada guru. Keterlambatan pengumpulan tugas menyebabkan siswa belum mencapai hasil belajar yang optimal. Alasan yang terkait disampaikan RZA kepada orang tua adalah karena RZA kurang memahami materi karena pemberian tugas tidak disertai penjelasan yang jelas. RZA juga terpengaruh ajakan teman untuk bermain dari pada mengerjakan tugas sekolah. Hasil penelitian ini juga seejalan dengan teori Samani dan Hariyanto (2020) menjelaskan bahwa tanggung jawab merupakan sebuah sikap dalam diri seseorang yang menunjukkan sikap mengetahui dan melaksanakan apa yang dilakukan sebagaimana yang diharapkan oleh orang lain. berdasarkan pernyataan Muchals dan Hariyanto maka tanggung jawab ini merupakan sesuatu hal pekerjaan dengan penuh rasa memiliki, disiplin, dan empati.

Hasil observasi selanjutnya dari informan kedua yaitu RAP. Televisi adalah salah satu faktor menghambat penanaman karakter yang dilakukan oleh orang tua terhada siswa RAP. Selain itu hobi bermain RAP menyebabkan ia lupa waktu sehingga melupakan beberapa nasehat dan aturan orang tua. Hasil observasi menunjukkan bahwa RAP juga mengumpulkan tugas dengan benar dan rapi. RAP selalu didampingi oleh Ibu SK dalam mengerjakan tugas. Sebagaimana yang disampaikan oleh orang tua RAP yaitu.

"Bu, apa anak selalu mengumpulkan tugas-tugasnya dengan tepat waktu?"

"Anak saya selalu mengumpulkan tugas dengan rapi dan disiplin waktu."

"Anak melakukan tugas daringnya dengan baik."

"Iya mbak, saya selalu mengajarkan anak untuk bertanggung jawab terhada semua tugastugasnya. Kalau tidak diwasi pasti tidak dikerjakan.” (1 Mei 2021)

Anak kurang mampu melaksanakan tugas rumah yang diberikan tanpa perintah dengan baik. RAP melakukan tugas rumah namun sering tidak melkukan karena bermalasan sembari bermain handphone atau menonton televisi. RAP akan mengerjakan tugas apabila sudah ditegur oleh orang tua. Sebagaimana yang telah disampaikan orang tua RAP yaitu.

"Apa anak dirumah melakukan tugas rumah atau tugas sekolah dengan baik dan teratur?"

"Anak tetap melakukan tugas rumah, tetapi lebih sering tidak karena bermalas-malasan bermain HP dan menonton televisi. Baru melaksanakan tugas rumah jika ditegur."

"Saya memberi hukuman agar anak tidak mengulanginya lagi."

"Faktor apa yang mengakibatkan anak tidak disiplin dan bertanggung jawab, Bu?

"Faktor penghambatnya ya bermain HP dan Televisi, Mbak." (1 Mei 2021)

Kendala ini sering dihadapi orang tua dikarenakan anak terlalu asyik menonton televisi. Hasil penelitian ini sesuai dengan hasil penelitian Hanif (2013) yang menyatakan bahwa karakter disiplin dan tanggung jawab tersebut dapat dipengaruhi beberapa faktor yaitu faktor instrinsik adalah faktor yang berasal dari dalam individu, meliputi psikologi, seperti minat, motivasi, bakat, konsentrasi, dan kemampuan kognitif. Sedangkan faktor ekstrinsik adalah faktor yang berasal dari dorongan lingkungan luar diri individu meliputi lingkungan keluarga, lingkungan sekolah, dan lingkungan masyarakat.

Dalam proses pendampingan terhadap anak, Ibu SK selalu memberikan motivasi kepada anak agar anak semagat belajar dan rajin mengerjakan tugas yang diberikan guru. Namun kendala anak malas dalam mengerjakan tugas. Kendala ini seringkali dihadapi orang tua dikarenakan anak terlalu asik menonton televisi dan bermain handpone. Observasi menunjukkan bahwa Ibu SK berusaha membiasakan sikap disiplin dan tanggung jawab kepada anak selama di rumah. 
3068 Analisis Karakter Disiplin dan Tanggung Jawab Siswa Sekolah Dasar pada Masa Pembelajaran Daring - Reni Sofia Melati, Sekar Dwi Ardianti, Much Arsyad Fardani

DOI: https://doi.org/10.31004/edukatif.v3i5.1229

Subjek penelitian yang ketiga adalah FEA. Hasil observasi menunjukan bahwa faktor yang menghambat pelaksanaan disiplin dan tanggung jawab anak selama masa pandemi adalah sifat malas anak. Terkadang anak lupa mengerjakan tugas karena malas mengerjakan dan menunda-nunda pekerjaan. Faktor ini dialami oleh subjek penelitian lainnya yang menunjukkan bahwa faktor yang mempengaruhi karakter disiplin dan tanggunng jawab anak adalah rasa malas dari dalam diri anak. Hal ini sesuai dengan pernyataan dari Bapak BJ selaku orang tua FEA yaitu.

"Adakah faktor yang menjadi penghambat anak disiplin dan bertanggung jawab selama pembelajaran daring, Pak?"

"Ada mbak, sifat anak yang malas membuat anak terkadang lupa akan tugasnya."

"Anak mengumpulkan tugas dengan tepat waktu, tetapi kalau mengerjakan terkadan sedikit mepet dengan waktu pengumpulannya. Alhasil pekerjaanya tidak maksimal karena dikerjakan dalam waktu yang singkat dan terburu-buru."

"Ada juga faktor lain yaitu sering disamperin teman-temannya untuk diajak bermain."

“Anak juga sering menganggap bahwa sekolah libur karena pandemi ini." (3 Mei 2021)

Sifat malas ini menghambat anak dalam disiplin mengerjakan tugas. Anak selalu menunda-nunda dalam mengerjakan tugas sehingga seringkali menunggu waktu yang mepet atau menunggu perintah dari orang tua. Meskipun tepat waktu dalam pengumpulannya, namun kurang maksimal karena dikerjakan dalam waktu yang singkat dan terburu-buru. Hal lain juga dikarenakan setiap hari anak selalu disamperin teman-temannya diajak bermain. Jadi faktor lain penghambat disiplin dan tanggung jawab FEA adalah dari lingkungan dan teman sebaya. Hal ini sejalan dengan hasil penelitian dari Rachmayanti \& Gufron (2019) mengemukakan bahwa faktor yang menghambat penanaman pendidikan karakter pada anak ada dua faktor, faktor dalam dan faktor luar. Faktor luar dipengaruhi oleh lingkungan keluarga, lingkungan masyarakat, dan teman sebaya, sementara faktor dari dalam adalah dari diri siswa itu sendiri.

Anak kurang patuh terhadap aturan atau kurang disiplin dalam penugasan dikarenakan adanya faktor penghambat. Adapun faktor ang menghambat pelaksanaan disiplin dan tanggung jawab anak selama pandemi adalah sifat malas anak. Sifat malas ini menghambat anak dalam displin dan berdanggung jawab mengerjakan tugasnya. Anak selalu menunda-nunda dalam mengerjakan tugas sehingga seringkali waaktu yang mepet. Berdasarkan kondisi ini maka FEA dikategorikan memiliki tingkat disiplin dan tanggung jawab yang sedang karena terkadang malas mengerjakan tugas.

Subjek penelitian yang keempat adalah ananda VA. Hasil observasi menunjukkan VA datang sesuai dengan waktu yang dijadwalkan dan tepat waktu mengambil dan mengumpulkan tugas kesekolah selama daring. VA selama pandemi disiplin dalam menggunakan waktunya untuk mengerjakan tugas-tugasnya. Sikap disiplin VA dikarenakan orang tua VA yang selalu mendampingi VA setiap hari. Hal ini menunjukkan VA kurang bertanggung jawab dengan dirinya sendiri. Tanggung jawab pada taraf yang paling rendah adalah kemampuan seseorang untuk menjalankan kewajiban karena dorongan dari dalam dirinya.

Namun, terkadang terdapat momen anak kurang mood sehingga kurang patuh atau melanggar aturan yang telah dilakukan. Rasa malas juga terkadang menyebabkan anak kurang mood dalam mengerjakan atau menyelesaikan tanggung jawabnya terhadap tugas yang dimiliki. Hasil observasi menunjukkan bahwa terkadang terdapat momen anak kurang mood sehingga kurang semangat dalam menjalankan perintah atau penyelesaian penugasan. Apabila anak sedang bagus moodnya maka anak akan patuh terhadap perintah. Hal ini sesuai pernyataan dari Ibu SL selaku orang tua VA yaitu.

"Bu, apa anak bertanggung jawab terhadap tugas-tugas yang dimilikinya?'

"Kadang iya kadang tidak, tergantung mood anak pada hari itu. Mood anak selalu beruba-ubah setiap harinya mbak."

"Apa ada faktor lain yang mengahambat karakter tanggung jawab anak selain mood anak Bu?"

"Ada, anak biasanya bermain game di HP tapi terkadang bermain bersama temannya hingga tak 
3069 Analisis Karakter Disiplin dan Tanggung Jawab Siswa Sekolah Dasar pada Masa Pembelajaran Daring - Reni Sofia Melati, Sekar Dwi Ardianti, Much Arsyad Fardani

DOI: https://doi.org/10.31004/edukatif.v3i5.1229

kenal waktu." (5 Mei 2021)

Salah satu yang sering mempengaruhi mood anak sekaligus faktor penghambat dalam penanaman karakter disiplin dan tanggung jawab anak adalah anak lebih menyukai bermain game di handphone. Selama pembelajaran daring ananda VA mengumpulkan dan mengerjakan tugas sekolah sesuai dengan waktu yang diberikan oleh guru karena selama masa belajar ananda VA selalu didampingi oleh orang tua. Ananda VA selalu mengumpulkan sesuai waktu yang ditetapkan oleh guru. Hal ini sesuai dan sejalan dengan penelitian Rahayu (2016) bahwa siswa yang bertanggung jawab adalah siswa yang mampu mengerjakan tugasnya dengan baik. Mengerjakan tugas sekolah adalah suatu kewajiban dan tanggung jawab sebagai seorang siswa yang hasilnya akan diraih dimasa depan. Melakukan tugas sendiri dengan senang hati dapat digambarkan dengan mengerjakan tugas tanpa merasa terbebani dan tidak tergantung pada orang lain (mandiri) dalam belajar dengan berusaha semaksimal mungkin.

Kesimpulannya adalah berdasarkan hasil penelitian menunjukkan bahwa terdapat berbagai macam faktor yang mempengaruhi disiplin siswa selama pembelajaran daring. Adapun faktor yang mempengaruhi disiplin siswa adalah adanya pengaruh teman, pengaruh handphone, dan pengaruh televisi. Siswa tidak mampu menggunakan waktu belajar dengan baik dan maksimal. Hal ini dikarenakan siswa lebih suka menghabiskan waktunya untuk bermain dengan teman, bermain handphone, dan menonton televisi. Hal ini menyebabkan siswa melupakan beberapa nasehat dan aturan orang tua. Kekurangan dari pelaksanaan pembelajaran daring adalah siswa yang tidak antusias dan tidak aktif selama kegiatan belajar mengajar serta guru tidak dapat memantau siswa secara langsung selama pembelajaran (Fathonah, U., \& Bukhori, 2021).

Adapun faktor yang mempengaruhi tanggung jawab siswa selama pembelajaran daring yaitu rasa malas dari dalam diri siswa. Siswa baru akan menyelesaikan tugasnya setelah ditegur oleh orang tua. Sesuai dengan pendapat Ningsih (2015) yang menyatakan adapun faktor yang mempengaruhi tanggung jawab siswa adalah adanya rasa malas dalam diri siswa. Rasa malas dalam diri siswa menyebabkan siswa tidak mampu menggunakan waktu belajar dengan baik dan maksimal. Siswa senang menunda-nunda pekerjaan. Pekerjaan yang ditunda-tunda akan mengakibatkan siswa terburu-buru dalam menyelesaikannya dan akhirnya hasil pekerjaan menjadi kurang optimal.

Dampaknya siswa kurang mampu menyelesaikan tugas sekolah lebih awal. Siswa sering terlambat dalam mengumpulkan tugas yang telah diberikan oleh guru. Siswa belum bisa mengumpulkan tugas dengan baik. Kesimpulannya adalah terdapat berbagai macam faktor yang mempengaruhi disiplin siswa berasal dari diri siswa atau faktor internal adalah adanya pengaruh teman, pengaruh handphone dan televisi. Terdapat berbagai macam faktor yang mempengaruhi tanggung jawab siswa selama daring berasal dari diri siswa atau faktor internal adalah rasa malas dalam diri siswa yang menyebabkan siswa menunda-nunda menyelesaikan pekerjaan. Sesuatu dalam diri siswa ini adalah karakter sehingga tanpa adanya karakter tanggung jawab maka siswa juga tidak akan menyelesaikan tanggung jawabnya. Sejalan dengan pernyataan Yasin (2018) bahwa kegiatan pelaksanaan tugas ini dapat diidikasikan seseorang memiliki nilai karakter yang bertanggung jawab dengan baik. Berdasarkan penjabaran diatas, maka kesimpulan dari ciri-ciri siswa yang memiliki tanggung jawab adalah melaksanakan tugas sepenuh hati, menerima resiko atas apa yang dilakukan, melakukan tugas sepenuh hati, menerima resiko atas apa yang dilakukan, melakukan kegiatan sekolah, dan mengajukan solusi atas pemecahan masalah. Nilai karakter merupakan pedoman yang mendorong seseorang melakukan suatu tindakan yang nantinya tersebut dapat dicirikan baik buruknya karakter seseorang. Tanggung jawab merupakan nilai moral penting dalam kehidupan bermasyarakat.

Penelitian ini memiliki kelebihan yaitu menganalisis karakter disiplin dan tanggung jawab anak SD pada masa pembelajaran daring. Analisis karakter disiplin dan tanggung jawab kepada anak sangat diperlukan untuk dapat mengetahui faktor-faktor yang menyebabkan anak mengalami penurunan dan mengetahui solusi penanganannya untuk membuat karakter disiplim dan tanggung jawab anak lebih baik dimasa pembelajaran daring akibat salahnya penggunaan HP pada anak. 
3070 Analisis Karakter Disiplin dan Tanggung Jawab Siswa Sekolah Dasar pada Masa Pembelajaran Daring - Reni Sofia Melati, Sekar Dwi Ardianti, Much Arsyad Fardani

DOI: https://doi.org/10.31004/edukatif.v3i5.1229

Kemudian keterbatasan temuan yang saya temukan setelah analisis data yaitu penelitian ini hanya sebatas menganalisis karakter disiplin dan tanggung jawab saja, tidak semua karakter yang terdapat dalam UU No. 20 tahun 2003 dapat diteliti. Setelah melakukan penelitian ini dapat menambah referensi penelitian tentang karakter disiplin dan tanggung jawab dimasa pandemi, karena sebelum penelitian ini dilakukan penelitian terdahulu hanya meneliti karakter disiplin dan tanggung jawab sebelum pandemi Covid-19 ada.

\section{KESIMPULAN}

Selama Pandemi Covid-19, pembalajaran yang semula luring berubah menjadi daring mengakibatkan menurunnya karakter disiplin dan tanggung jawab pada siswa SD. Dari pembahasan di atas, dapat ditarik kesimpulan bahwa banyak faktor yang mengakibatkan penurunan karakter siswa. Berbagai macam faktor yang mempengaruhi disiplin dan tanggung jawab siswa selama pembelajaran daring. Adapun faktor yang mempengaruhi disiplin dan tanggung jawab siswa, faktor eksternal adalah adanya pengaruh teman sebaya, pengaruh handphone, dan pengaruh televisi. Sedangkan faktor internal adalah adanya rasa malas dari dalam diri siswa. Oleh karena itu, orang tua harus lebih menyediakan waktunya untuk mendampingi anaknya dalam belajar dan kegiatan sehari-harinya. Juga memberikan motivasi, nasehat, dan nilai-nilai tanggung jawab kepada anak.

\section{DAFTAR PUSTAKA}

Ardiana, D. P. ., Dwiyanto, H., Irawan, I., Mahawati, E., Simarmata, J., Susanti, S. ., Sudra, R. ., Yuliani, M., \& Yuniawati. (2020). Pembelajaran Daring Untuk Pendidikan: Teori Dan Penerapan. Yayasan Kita Menulis.

Ardiansyah, H. (2013). Faktor - Faktor Yang Mempengaruhi Disiplin Belajar Siswa Kelas Xii Jurusan Administrasi Pekantoran Di Smk Nu 01 Kendal Tahun Pelajaran 2012/2013. Https://Lib.Unnes.Ac.Id/19237/

Asyari, M. M., Ismaya, E. A., \& Ahsin, M. N. (2021). Nilai-Nilai Pendidikan Karakter Dalam Tradisi Apitan Masyarakat Singocandi Kudus. WASIS: Jurnal Ilmiah Pendidikan, 2(1), 34-40. Https://Doi.Org/10.24176/Wasis.V2i1.5764

Dole, F. E. (2021). Edukatif: Jurnal Ilmu Pendidikan Pengaruh Pendidikan Karakter Terhadap Kedisiplinan Peserta Didik Di Sekolah Dasar. 3(6), 3675-3688.

Fathonah, U., \& Bukhori, H. A. (2021). Analisis Kesulitan Siswa Dalam Pelaksanaan Pembelajaran Bahasa Jerman Secara Daring Selama Pandemi Covid-19 Di Sekolah Menengah Atas. Edukatif: Jurnal Ilmu Pendidikan, 3(4),(4), 1152-1160. Doi: Https://Doi.Org/10.31004/Edukatif.V3i4.493

Hapsari, R. W., Ardianti, S. D., \& Ismaya, E. A. (2021). Jurnal PAJAR ( Pendidikan Dan Pengajaran ) Volume 5 Nomor 3 Mei 2021 | ISSN Cetak: 2580 - 8435| ISSN Online: 2614 - 1337 DOI: Http://Dx.Doi.Org/10.33578/Pjr.V5i3.8310 Parents ' Role In Assisting Children In Online Learning During Covid- 19 Pandemic Pe. 5, 656-662.

Kemendiknas. (2010). Bahan Pelatihan Penguatan Metodologi Pembelajaran Berdasarkan Nilai-Nilai Budaya Untuk Membentuk Daya Saing Dan Karakter Bangsa.

Larasati, E. D. (2017). Pendidikan Karakter Mandiri Melalui Kegiatan Ekstrakurikuler Pramuka Di Sekolah Dasar. Jurnal Pendidikan Guru Sekolah Dasar, 5(6), 384-390.

Lickona, T. (2013). Pendidikan Karakter: Mendidik Untuk Membentuk Karakter Bagaimana Sekolah Dasar Mengajarkan Sikap Hormat Dan Tanggung Jawab. Bumi Aksara.

Ningrum, R. W., Ismaya, E. A., Fajrie, N., \& Artikel, S. (2020). Faktor - Faktor Pembentuk Karakter Disiplin 
3071 Analisis Karakter Disiplin dan Tanggung Jawab Siswa Sekolah Dasar pada Masa Pembelajaran Daring - Reni Sofia Melati, Sekar Dwi Ardianti, Much Arsyad Fardani

DOI: https://doi.org/10.31004/edukatif.v3i5.1229

Dan Tanggung Jawab Dalam Ekstrakurikuler Pramuka. 2020, 3(1), 105-1117.

Ningsih, T. (2015). Implementasi Pendidikan Karakter. Stain Press.

Patmawati, S. (2018). Penerapan Pendidikan Karakter Disiplin Dan Tanggung Jawab Siswa Di Sd Negeri No. 13/1 Muara Bulian. Pendidikan, 1(13), 1-16.

Pohan, A. E. (2020). Konsep Dan Model Pendidikan Karakter. CV Sarnu Untung.

Prabowo, S. H., Fakhruddin, A., \& Rohman, M. (2020). Peran Orang Tua Dalam Pembentukan Karakter Anak Di Masa Pandemi Covid-19 Perspektif Pendidikan Islam Abstrak Kata Kunci: Peran Orang Tua , Pendidikan Karakter , Pandemi Covid-19 , Pendahuluan Keberhasilan Pendidikan Formal Yang Ditempuh Seorang Anak Tida. Pendidikan Islam, 11(2), 191-207.

Prastika, M. D. W. (2018). Penanaman Karakter Disiplin Dan Tanggung Jawab Melalui Kegiatan Ekstrakurikuler Teater Di SMA Negeri 1 Andong Kabupaten Boyolali. Universitas Muhammadiyah Surakarta.

Rachmayanti, S. Intan, \& Gufron, M. (2019). Analisis Faktor Yang Menghambat Dalam Penanaman Pendidikan Karakter Disiplin Pada Siswa Di Sdn 02 Serut. Jurnal Ilmu-Ilmu Sosial, 16 (1)(2019).

Rahayu, R. (2016). Peningkatan Karakter Tanggung Jawab Siswa SD. Psychology Applied To Work: An Introduction To Industrial And Organizational Psychology, Tenth Edition Paul, 53(9), 1689-1699. Http://Repository.Uin-Suska.Ac.Id/7401/3/BAB II.Pdf

Ramadhani, I. R., Fathurohman, I., \& Fardani, M. A. (2020). Jurnal Amal Pendidikan. Jurnal Amal Pendidikan, 1(2), 96-105.

Rangga, K., Saputro, J., Ulya, H., \& Fardani, A. (2021). Pengaruh Perhatian Orang Tua Selama Pembelajaran Daring Terhadap Prestasi Belajar Siswa Sd 2 Karangrowo. X, 1-7.

Resti, F. I. (2017). Pembentukan Karakter Disiplin Dan Tanggung Jawab Siswa Sma Negeri 1 Demak Melalui Program Tertib Parkir Di Sekolah. Universitas Negeri Semarang.

Samani, M., \& H. (2020). Konsep Dan Model Pendidikan Karakter. PT Remaja Rosdakarya.

Samani, M., \& Hariyanto. (2020). Konsep Dan Model Pendidikan Karakter. PT Remaja Rosdakarya.

Triyani, E., Busyairi, A., \& Ansori, I. (2020). Penanaman Sikap Tanggung Jawab Melalui Pembiasaan Apel Penguatan Pendidikan Karakter Siswa Kelas Iii. Jurnal Kreatif: Jurnal Kependidikan Dasar, 10(2), $150-154$.

Uddiin, A. R. (2016). Edisiplinan Siswa Dalam Mengikuti Kegiatan Sekolah Studi Kasus Di Sd Negeri Panasan Sleman. Universitas Negeri Yogyakarta.

Wanabuliandari, S., \& Ardianti, S. D. (2018). Pengaruh Modul E-Jas Edutainment Terhadap Karakter Peduli Lingkungan Dan Tanggung Jawab. Scholaria: Jurnal Pendidikan Dan Kebudayaan, 8(1), 70-79. Https://Doi.Org/10.24246/J.Js.2018.V8.I1.P70-79

Yasin, M. (2018). Implementasi Pendidikan Karakter Disiplin, Tanggung Jawab Dan Rasa Hormat Di Min 05 Bandar Lampung. Http://Repository.Radenintan.Ac.Id/5030/

Zubaedi. (2011). Desain Pendidikan Karakter. Kencana Penada Media Group. 